Received: 8. 9. 2014.

Accepted: 30. 3. 2015.

\begin{tabular}{|c|c|}
\hline \multirow[t]{2}{*}{$\begin{array}{c}\text { Original } \\
\text { Article }\end{array}$} & $\begin{array}{l}\text { Marina D. Milovanović }{ }^{1} \text {, MA } \\
\text { Marina S. Radić Branisavljević }{ }^{2} \text {, Jasna D. Petrović }\end{array}$ \\
\hline & Singidunum University, Belgrade \\
\hline
\end{tabular}

\title{
The use of ICT in learning language for specific purposes
}

Summary: Globalization as a 20th century phenomenon continued intensively in the 21st century and - coupled with a substantial economic crisis - has led to a massive migration of experts from all fields across the countries and continents. Together, these phenomena have forced people to seek employment not only in different cities but also in different countries and continents. Furthermore, scientists and researchers are changing their places of residence to do joint researches, which are intensifying in the XXI century.

These migrations have led to a growing need for learning foreign languages, and not only the spoken language: oftentimes, people have to learn language for specific purposes to be able to have successful communication with their colleagues from other countries.

Development of modern technologies has changed the way we learn language. Learning is no longer static, classroom-bound, relying on textbooks and teachers. It uses multimedia while applying ICT and is quite often done online, with a teacher who is, of course, still present, but whose role has undergone a complete change, and a new one is also being adapted to alterations, embracing the advantages of the new technologies utilization in the language learning processes, especially in learning language for specific purposes.

The aim of the paper is to show the lecturers' role in foreign languages teaching, the use of ICT in foreign languages instruction, and the teacher-student relationship. The results of the survey and statistical data show that students have a great interest in learning LSP online, which is particularly popular among the employed. Hence we may conclude that IT and ICT greatly facilitate and improve LSP learning, since materials and courses are available at all times, and their number is constantly rising.

Key words: Foreign languages, ICT, LSP, modern technologies, teacher

\footnotetext{
1 mmilovanovic@singidunum.ac.rs

2 mradic@singidunum.ac.rs

3 jpetrovic@singidunum.ac.rs
} 


\section{Introduction}

The modern time, 21st century and globalization have led to a series of changes in lifestyle and in the way we do business. In many ways, these changes have also had a profound effect on education. Whether it is learning a foreign language for general or for specific purposes, ICT is considered an almost indispensable part of teaching. Great many researches have been undertaken in the last two decades on the subject matter of ICT and a conclusion we may draw is that ICT is recognized and accepted as an important element of foreign language instruction (Zhao, 2003). The changes in modern technology, which are happening on an almost daily basis, have brought considerable alterations in the LSP teaching structure. The Web is no longer a place one only uses to read. It has become a place where one reads, writes, listens, and speaks, an ideal place for learning language for specific purposes where all four language skills are being equally perfected and developed.

The purpose of this paper is to show examples of good practice and adequate use of ICT in foreign language teaching, with special emphasis on LSP. The work will feature the results of a survey, the purpose of which was to point to the importance and prevalence of the Internet in foreign language teaching, and pinpoint the drawbacks listed by respondents which should facilitate future improvement.

\section{Methods}

This paper will present research important for the application of ICT, mostly in foreign language teaching. By analyzing and synthesizing the recent results, and using statistical data and results obtained through the survey, this paper will illustrate the importance of the use of ICT in foreign language teaching, as well as the changes related to work and relationship between the professor and the student. The change in the manner of work, as well as the motivation of students, who generally learn language for specific purposes to be able to advance in a particular job, resulted in the relationship between the student and the professor becoming a partnership (Vučo, et al 2009). The motivation of students is raised to a higher level, and with the availability of materials on the Internet being unlimited and ceaseless (24/7), students themselves become programme creators, while professors assume the role of coordinators.

\section{Traditional vs. online foreign language learning}

A traditional manner of learning foreign languages, which implied an active role of a teacher and a passive role of a student (Warrschauer, Meskill, 2000) today is completely replaced with a new and a different mode of work. The traditional manner of work underwent a gradual change, in accordance with the novelties and changes that happened slowly over the years. Unlike that process, the changes of today are happening almost on a daily basis and teachers are expected to adapt to them and use information technologies while working with the digital generation (Davies, Elder, 2006: 82). The research conducted at a university in Belgrade showed that students have expressed considerable interest in enrolling in online courses and foreign language courses, which entail an active use of computers and electronic devices. However, as a drawback or a fault of this method of work they cited the inability to get answers and explanations the moment they make a mistake and absence of teachers who would point to the error straight away (Radić Branisavljević, Milovanović, 2014).

A large number of researches have shown that the absence of communication with a professor in real time and the inability to give a feedback have led to a loss in motivation in great many foreign language students and their dropping online courses, which is further substantiated by a large number of online courses being left unfinished (Stanić, 
Gavrilović, 2011). It is precisely because of this that many argue that in the classroom students motivate each other and foster competitive spirit, which strengthens the motivation in course attendants.

\section{ICT in learning language for specific purposes}

The use of ICT in teaching a foreign language and a language for specific purpose pose two most frequent challenges which foreign language teachers face. Namely, the majority of faculties of philology teach or have taught language for general purposes, and it is towards the end of graduate studies that foreign language students have encountered for the first time some modern articles containing specialized terminology. However, currently the situation in the market is such that there is an increasing demand for studying language for specific purpose. In the last few years foreign languages have been taught at nearly all faculties. But, it is not seldom that LSP teachers have completed LGP courses in their studies (Vučo, et al, 2009), and hence require additional training to master language for specific purposes.

Unlike students who study the language for general purposes, students who study language for specific purposes are additionally motivated. Namely, for these students a foreign language is necessary means for achieving their utmost end: making progress at work and in a particular profession, therefore the thirst for knowledge and passing and ultimately acquiring internally-recognized certificates tie in with the desire to climb up the career ladder and obtain a job abroad.

In the section below we will show how foreign language teachers, using ICT, can organize classes for learning language for specific purposes.

ICT in teaching, both language for general and specific purposes, can be taught in three different and yet interconnected aspects:

1. ICT in preparing teaching material
2. ICT in the classroom

3. ICT for self-study

\section{ICT in preparing teaching material}

ICT, the Internet before all else, places at teachers' disposal the material that is modern, including a large number of articles, magazines, exercises and the like. In the majority of cases, a textbook is an essential teaching material, but professors have the freedom to expand and innovate it and to use social networks, blogs or forums to post new exercises and exchange them with colleagues from around the world. It depends solely on the teacher to what extent they will express creativity and innovativeness, and how well they will be able to find and adequately use the material for teaching language for specific purposes (Warrschauer, Meskill, 2000).

In conversation through Skype, teachers are able to continuously master their language skills and keep up with the way their colleagues across the world work.

The preparation of teaching material for LSP is a serious commitment and responsibility for teachers. Considering that course attendants or college students are planning to advance their knowledge or work abroad, it is highly likely that their expectations from professors will be much higher. In the light of the fact that professors sometimes have to seek help from students, when encountering some specialized terms, it is then that the role of teachers changes and they become coordinators and partners in the teaching process, as well as people who are learning something they had no previous knowledge of (Vučo, et al, 2009: 575).

Many textbooks, aspiring to meet the contemporary market demand halfway, are businessfocused from the beginner's level (A1) and students learn business terminology in a foreign language from the very start. In this case, the teacher's job is much easier. However, if a professor uses a textbook for LGP and teaches students business terminology 
tied to a specific profession, the preparation of material can take up a lot of time.

It is important to gradually introduce terminology and business situations students may encounter. This implies reading and translating specialized terminology, writing business letters, emails, preparing CVs and motivational letters in the target language and the like.

Cloud computing (Dropbox, Internet) is a new technology that enables access and sharing different kinds of folders and materials independent of the user's location. All needed information is contained in "the cloud" which users may easily access wherever they are. All they need is a computer and the Internet. There is no longer need to save, keep, record data, burn them on discs or save in removable usb flash drives. A well-known Dropbox service is closely linked to the aforestated as this is yet another modern way of storing files. In preparing their material, a teacher may have in the computer all the material that they need for a certain class or for the entire school year in one or in several folders. The folder/folders are placed in the Dropbox, after which the teacher chooses which users he's going to share the material with. Furthermore, the teacher may open their Dropbox anytime on any computer and use the material, presentations etc. Dropbox (Dropbox) is certainly very useful and frequently used lately by teachers and students alike.

\section{ICT in the classroom}

In order to implement ICT in the LSP teaching, it is a prerequisite that a classroom has a computer, the Internet connection and an overhead projector. The task of teachers is to - in addition to providing materials and specialized articles - enable and create a real business environment for their students. With examples from YouTube that could feature such business environment or a business meeting, students will have the task to present business situations, business meetings or job interviews. There is an option to record such situations, which would be replayed for students to hear and analyze and see the mistakes they may have made. In electronic classrooms it is also possible to organize an email exchange between a number of students, while in this situation the professor's role is that of a students' coordinator and a manager in the teaching process.

In some well-equipped classrooms it is also possible to simulate a video conference, a form of meeting that is quite common in the world today. Namely, it enables business people to hold a meeting at the same time - from distant places, even from different continents - using the Internet, computer, Skype, and make important business decisions. Such meetings can be simulated in the classroom.

\section{ICT for self-study}

In this teaching process, foreign language teachers bear great responsibility. Today, when every person has a computer, Internet, email, Facebook account, Twitter account, blog and the like, an independent approach in language learning encompasses these means of communication without fail. The professor is a person who should give tasks that students ought to complete on their own, and he is to coordinate online (Learning and teaching practice).

Student self-study using ICT largely refers to websites, platforms and virtual classrooms.

Internet websites such as www.livemoccha. com or www.ver-taal.com enables students to make progress and learn foreign languages in a quite interactive and dynamic way. Some websites also have a network of teachers who are native speakers and who mentor students by pointing to mistakes and explaining potential difficulties.

It has already been said that students who learn language for specific purposes are more motivated, because the chosen foreign language is something that is closely connected with their profession, employment and career development. 
Those LSP course attendants who already have jobs are the ones who finish the majority of online courses. They are motivated and individual work suits them well. They are also able to organize their schedule and adjust it to learning LSP. Online studying enables them to use materials and take tests 24/7, while also giving them freedom to set work and progress dynamics. Considering that learning a foreign language is closely linked with their profession, they do not need an environment and peer support, but it is in their interest to connect with colleagues and experts from different fields abroad. In addition to applying for online courses and platforms for learning LSP, foreign language learners may also take private lessons through Skype or use it for communicating with native speakers of the target language. Independent work also encompasses email exchange (with other course students or the teacher), posting important units topic-wise, on Facebook, blog, chat, etc.

The need to keep the contact with a student, to keep a record of his development and assess his performance has led to both development and perfection of the tool for managing learning processes called Learning Management System (LMS). One of the best Open Source Learning Management Systems Moodle platform (Moodle).

Moodle is a package for creating web-based courses and is quite favourable for learning LSP with a great opportunity for personalization that enables the teacher to create on-line courses with exceptionally rich interaction (Stanić, Gavrilović, 2011). According to the current statistical data, the number of users is $71,919,458$, and the number of users in terms of different courses on Moodle platform is $103,589,549$, whereas the number of teachers on the platform is 1,155,662 (Moodle). Moodle makes it possible to develop all four language skills. The exercises on the platform are interactive, they are done online and the results may be seen right away.

Aside from platforms, foreign language learning increasingly uses virtual classrooms and in the last couple of years so-called 3D virtual classrooms are being developed. Students are located in the real-time environment where they learn a foreign language. At the University in Bielefield there is a $3 \mathrm{D}$ amphitheatre, where students come to the University through their avatars, listen to lectures and attend office hours.

Quite an interesting and a useful example is a 3D classroom for the Spanish language, which was premiered at the international conference in $\mathrm{Ma}$ drid. Each course attendant in this 3D classroom has his avatar, which is located in the capital of Spain, Madrid. The students had the task to find a way, using their avatars, to the final goal, the Prado $\mathrm{Mu}$ seum. By engaging in the conversation with other course attendants, i.e. their avatars, their task was to find their way around, find the right transport and reach the goal (Ibáñez, et al, 2010).

Virtual classrooms enable experts from certain fields to establish a connection and to exchange, by learning a foreign language, experiences from a certain profession.

Considering that we've seen the example for a 3D virtual classroom along with the example of setting students, i.e. their customized avatars of choice in a realistic Madrid environment, it would be a good idea to create virtual offices, firms, business centres, hospitals, courts, restaurants and the like, where course attendants could, in a real environment and with other attendants, work and master their business skills in a foreign language. It is believed that the work in a $3 \mathrm{D}$ environment has a positive effect on students, especially those who are shyer or not quite communicative. In this way, practically without leaving the room, students can lose restraints, communicate and learn.

The movement that is attempting to introduce 3D technologies in the curriculum and intensify its use is called MMLO (Massively Multi - user Online Learning). "The MMOL platforms are mixed environments that bring an interactive learning space with the use of $3 \mathrm{D}$ technologies - 3D graphics, seri- 
ous games, virtual reality, realistic simulations, mirror worlds, augmented reality, synchronous communication tools, live chat, web cams, and rich digital media to build collaborative online course environments and classrooms in which individuals participate in a real or figurative presence (avatar). The MMOL platforms provide educators and students with the ability to connect and communicate in a way that greatly enhances the learning experience" (Lorenzo, 2010).

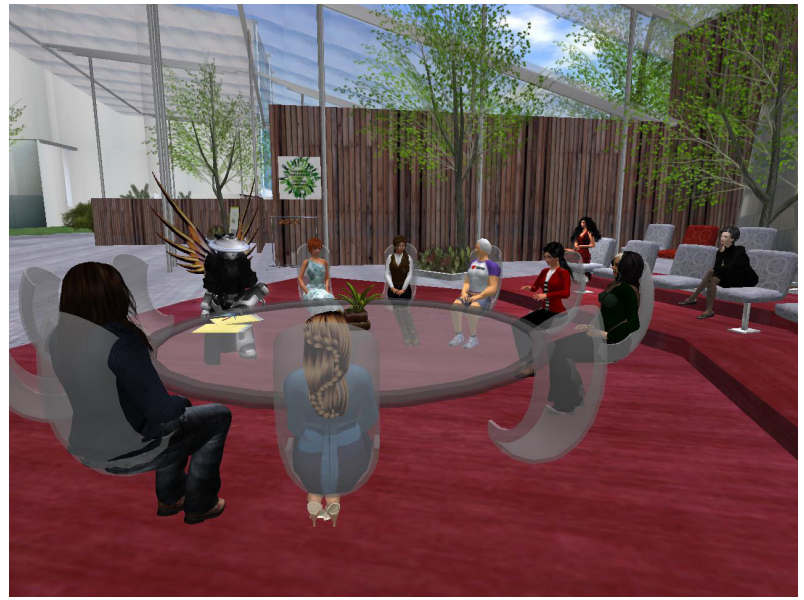

Image 1. Virtual roundtable (Source: Virtual Worlds Education Roundtable)

The professor is a person who is supposed to create the syllabus and the textbook students use, to modify and adjust it to the virtual environment and other activities that include ICT. It is only by doing so that the teaching process can be realized in a quality-way, and this certainly affects the moti- vation in students, emphasizes their independence and gives them a possibility to learn a foreign language at their own pace and in keeping with other duties and private obligations.

\section{Class model}

Textbook - Complete First Certificate (language for general purpose textbook, not for business) (Brook-Hart 2008: 5)

Level - B2 Upper-intermediate

Unit 4 - Food, glorious food

Number of lectures- 2 X $105 \mathrm{~min}$

Number of students in the group: 30

The unit from the textbook that is used for learning English language for specific purpose, can be changed, amended and adapted to suit the needs of specialized language, and classes can be organized using ICT. To successfully complete a teaching unit, aside from a textbook, the task of the teacher and students would be to prepare for the following additional activities:

Teacher: prepares the material that is connected with the professions in the catering industry, sets the following topics on either a blog or Facebook: restaurant, food (fruit, vegetables, desserts, meat, fish, sea food etc.), prepares YouTube videos related to restaurants, stores, food, dialogues, ordering and delivering food, and the like. Following this, students should make a CV and a motivational letter.

\begin{tabular}{|c|c|c|c|c|c|c|c|}
\hline $\begin{array}{l}\text { Unit } \\
\text { title }\end{array}$ & Reading & Writing & $\begin{array}{l}\text { Use of } \\
\text { English }\end{array}$ & Listening & Speaking & $\begin{array}{c}\text { Voacbu- } \\
\text { lary }\end{array}$ & Grammar \\
\hline $\begin{array}{l}\text { Food, } \\
\text { glorious } \\
\text { food }\end{array}$ & $\begin{array}{l}\text { Part 2: Learn- } \\
\text { ing about } \\
\text { food } \\
\text {-Identify- } \\
\text { ing cohesive } \\
\text { features }\end{array}$ & $\begin{array}{l}\text { Part 2: Review } \\
\text { of a restaurant }\end{array}$ & $\begin{array}{c}\text { Part 1: } \\
\text { Moso Moso } \\
\text { restaurant }\end{array}$ & $\begin{array}{c}\text { Part 4: The Slow } \\
\text { Food Movement } \\
\text {-Two candidates } \\
\text { doing Speaking } \\
\text { Part } 4\end{array}$ & $\begin{array}{c}\text {-Talking about } \\
\text { favourite dishes and } \\
\text { healthy eating } \\
\text { Part 4: Supporting } \\
\text { your opinions }\end{array}$ & $\begin{array}{c}\text { Food, } \\
\text { dish, meal }\end{array}$ & $\begin{array}{l}\text { So and } \\
\text { such } \\
\text { Too and } \\
\text { enough }\end{array}$ \\
\hline
\end{tabular}

Table 1. Preview of the book unit (Source: Complete First Certificate) 
Prior to the class, students should take photos and post on either the blog or Facebook relevant photographs according to categories, say what particular food is called and give examples for their use in a sentence. follows:

In the class, the work dynamics should be as

1. Discussion about food, type of food, restaurants and the like.

2. Overview of thematic blog, corrections, explanations, sentence examples.

3. Showing YouTube videos that simulate situations in restaurants, stores, in the kitchen and places where we meet with food and where food is prepared.

4. Introducing the topic of professions linked with food, analysis, what each employee needs to have, how they should behave and the like.

5. PPT presentations are used to show students how to make a CV, featuring the form they need to adhere to and learn about the content of the motivational letter

6. Students write their own CV, creating a profession that is related to hospitality or tourism.

7. In the next section, students are put in groups, some are interviewers, some are potential candidates for a job. Should conditions allow, candidates and employers can be in separated classrooms, and may have job interviews through a video conference.

8. If possible, students may be recorded, after which the recordings will be played to correct potential mistakes.

\section{Results}

For the purpose of the research, we have used statistic data and surveys carried out among the students of the University of Singidunum, which has had a distance learning option available since the school year 2005/2006. This option was introduced precisely owing to the development of Internet technologies and ICT that made this kind of studying possible. The statistical data showed that the number of students rose year-on-year (Graph 1), which is substantiated by the fact that a large number of people wish to continue or upgrade their current education, regardless of their age and working status, but for some reason they were not able to attend lectures regularly by being physically present at the faculty (Radić Branisavljević, Milovanović, 2014).

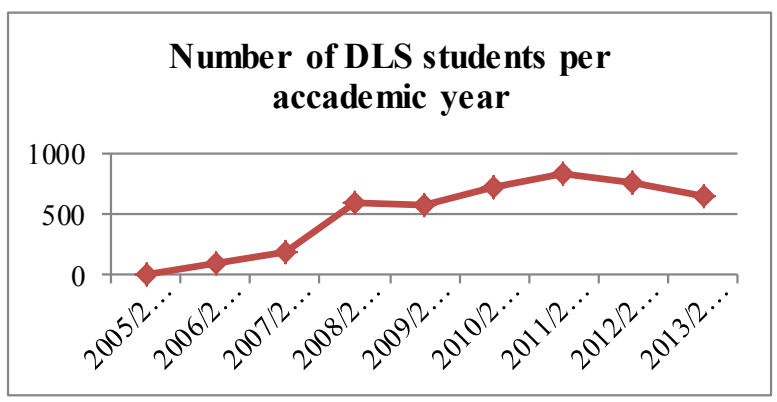

Graph1. The number of DLS students per academic year (Source: Singidunum University)

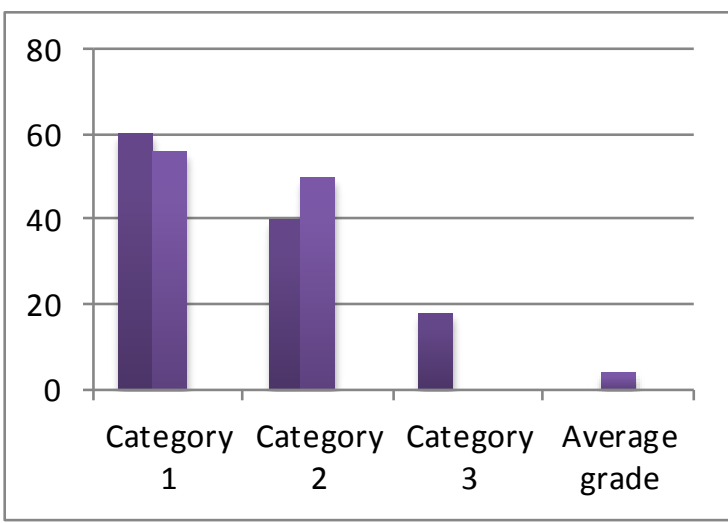

Graph 2. Survey results (own source) 
The survey encompassed 60 students who regularly attend University classes and regarded their need to use the Internet to study and learn foreign languages. All 60 students said that they have and use the Internet for studying purposes (graph 2, category 1 ). As many as $2 / 3$ of respondents have perceived positively the opportunity to use Internet for learning a foreign language, while even more students said that they regularly use Internet as a learning tool (graph 2, category 2). However, only $1 / 3$ of respondents deemed that it was possible to learn a language through the Internet, and yet $80 \%$ of all respondents attended an online course and/or plan to do so in the future (graph 2, category 3). As for their assessment of the Internet use in the classroom by teachers, an average grade of above 3.55 (graph 2) leads to a conclusion that students of today, who belong to the modern digital age, expect higher ICT implementation in teaching from their professors (Radić Branisavljević, Milovanović, 2014).

The results of the survey clearly confirm that even though all respondents have the Internet, which they use on a daily basis, they still do not think that it can serve as a serious tool for working and studying. They perceive it more as a means for fun and entertainment. Within the survey the respondents said that the major drawback in using the Internet for foreign language learning is absence of teachers, personal contact and feedback, that is explanations they can get straight away.

\section{Discussion}

The conclusion we may draw is that the Internet and ICT technologies have brought many novelties and improvements in foreign language teaching, especially in teaching language for specific purpose, because they enabled the use of practically endless source of information that is both authentic and modern. The information is available to students and teachers alike. Furthermore, ICT provided a new form of communication for students and teachers via platforms, forums, social networks, Skype etc. A great advantage of learning language online is the fact that course attendants are no longer time and classroom bound. Instead, they are free to organize their study time in keeping with their possibilities and interests. This is particularly convenient for foreign language students, since it enables them to learn a foreign language in line with their workrelated commitments.

Advantages of this technologically advanced way of learning a foreign language are manifold and they overshadow potential drawbacks. This is why we believe that ICT in language learning has brought considerable changes and dynamics in studying per se, as well as in communication and exchange of information around the globe. Further development of information technologies will advance the work and development of professors themselves, but it will also improve the level of knowledge of specialized language among employees and experts from different fields.

\section{References}

- Davies, A., Elder, C. (2006). The Handbook of Applied Lingüístics, Oxford: Blackwell Publishing.

- Lorenzo, C. M. (2010). MMOL platforms: Open 3D technologies in educational practices, from http://www. academia.edu/1225483/MMOL_Platforms_open_3D_learning_technologies_in_educational_practices (viewed 07.07.2014.)

- Dropbox. From www.dropbox.com (viewed 14.07.2014.)

- Facebook statistics. From http://www.statisticbrain.com/facebook-statistics/ (viewed 28.06.2014.)

- Brook-Hart, G. (2008). Complete First Certifiacate, Cambridge: Cambridge University Press. 
- Vučo, J., Ignjačević, A., Mirić, M. (2009). Jezik struke: teorija i praksa. Beograd: Zbornik radova sa Međunarodne konferencije, 574-575

- White, K. D. (2013).Cultutres and Communities in the Virtual World: Beginning the Exploration. In The IALLT Journal, from www.iallt.org/sites/default/files/04_white_cultures_and_communities_iallt_journal_43-2.pdf (viewed 20.12.2013.)

- Learning and teaching practice. From www.jisc.ac.uk/whatwedo/topics/learningteaching.aspx (viewed 11.02.2014.)

- Radić Branisavljević, M., Milovanović, M. (2014). Savremene tehnologije u nastavi stranih jezika. Beograd: Zbornik radova sa Međunarodne konferencije Sinteza, 500-505.

- Ibáñez M. B., García, J. J., Galán, S., Maroto, D., Morillo, D., Kloos, C. D. (2010). Multi-User 3D Virtual Environment for Spanish Learning - A Wonderland Experience. Madrid: International Conference on Advance Learning Technologies, 455-457.

- Warrschauer, M., Meskill, C. (2000). Technology and Second Language Teaching. In Handbook of undergraduate second language education: 303-318, from www.gse.uci.edu/person/warschauer_m/tslt.html (viewed 10.03.2014)

- Moodle statistics. From https://moodle.org/stats/ (Viewed 23.07.2014.)

- Stanić, N., Gavrilović, J. (2011). Komparativna analiza različitih sistema za učenje na daljinu.Bijeljina: Zbornik radova sa Međunarodne konferencije Sinergija, 139-143.

- Universität Bielefeld. From http://www.e-learning3d.de/ (viewed 23.07.2014.

- Zhao, B. Y. (2003). Recent Developments in Technology and language Learning: A Literature Review and meta Analysis. In Calico Journal, Vol.21 (1) 7-27. From https://calico.org/html/article_279.pdf (viewed 11.05.2013.) 


\section{мр Марина Д. Миловановић, Марина С. Радић Бранисављевић, Јасна Д. Петровић}

Универзитет Сингидунум, Београд

\section{Уйойреба ИКТ-а у насйави сйраної језика сйруке}

Глобализација као йојава ХХ века која се инйензивно настиавља и у ХХІ веку и изражена економска криза йослеgних іодина gовеле су gо велике миірације ситручюака из свих областии из јеgне земље у gруіуу. Ове йојаве зајеgно су условиле йойребу љуяи gа у йойрази за

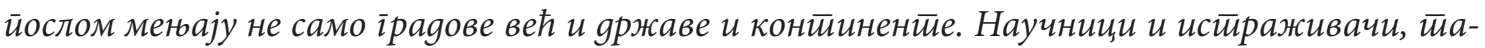
кође, меньају своја местиа стианована раяи уяружених исираживана која се инйензивирају y XXI веку.

Ове миіраиије су нужно наметинуле ӣотиребу за ученем сйраних језика, али не више само іоворноі језика, већ, све чешће, льуди морају gа уче и језик сйруке gа би найреgовали на йословним йољима и усиели gа остиваре усиетну комуникацију са својим колеїама из gруїих земаль. Са развојем савремених йехнолоіија gошло је gо ирромена и у начину учена језика. То

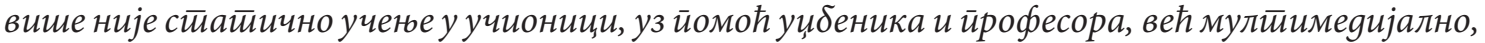
уз йримену ИКТ-а, врло честио и онлајн учење, уз, наравно, и gалье иррисуйноі ӣрофесора који, међуйим, саgа има йойиуно gруїачију улоїу и који се йакође ирилаїођава йроменама и

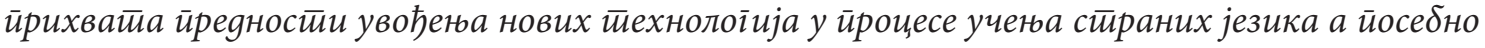
језика ситруке.

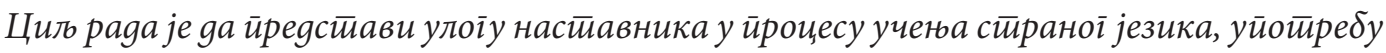
ИКТ-а у настиави сиираноі језика и однос између настиавника и ученика. Резулитайи

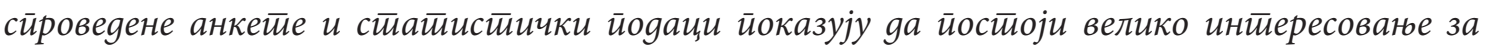

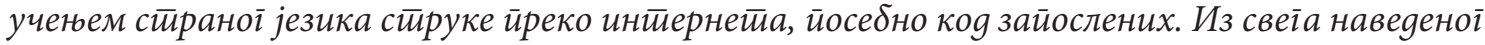
може се закључити gа информационе йехнолоїије и ИКТ олакшавају и унайређују йроцес

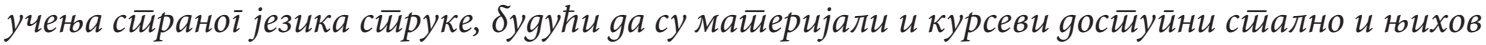
број се консиианйно йовећава. 